QUANTITY AT EXPENSE OF QUALITY?

MEASURING THE EFFECTS OF TECHNOLOGICAL M\&A ON

INNOVATION AND FIRM PERFORMANCE

\author{
by \\ Maria Chiara Di Guardo \\ University of Cagliari \\ Viale Fra Ignazio 74 - 09123 \\ Cagliari, Italy \\ diguardo@unica.it \\ Kathryn Rudie Harrigan \\ 701 Uris Hall \\ Columbia University \\ New York, NY 10027 USA \\ krh1@columbia.edu \\ Elona Marku \\ University of Cagliari \\ Viale Fra Ignazio 74 - 09123 \\ Cagliari, Italy \\ elona.marku@unica.it
}




\title{
QUANTITY AT EXPENSE OF QUALITY? \\ MEASURING THE EFFECTS OF TECHNOLOGICAL M\&A ON INNOVATION AND FIRM PERFORMANCE
}

\begin{abstract}
This study examines the effects of technological mergers and acquisitions (M\&A) on post-deal innovation and firm performance. We argue that technological M\&A lead to an increase of the innovation output in terms of patent counts while non-technological deals do not. By using the novel matching estimators and propensity score methods in order to take in consideration the endogeneity bias in the sample, we better capture the differences between technological and non-technological M\&A. Our empirical results showed that firms engaged in technological M\&A had lower innovation performance -in comparison to firms involved in non-technological deals- as reflected by a statistically significant decrease of the average quality of the inventive output, captured by citation-based patent analysis.
\end{abstract}




\section{INTRODUCTION}

In an ever more globalized and dynamic economy, firms attempt to gain and maintain competitive advantages while facing increasing financial performance pressures. In this context, mergers and acquisitions (M\&A) represent a strategic means not only of entering desirable markets (Brakman, Garretsen, \& Van Marrewijk, 2013; Chevalier, 2004) and integrating vertically and horizontally (De Man \& Duysters, 2005), but also of gaining new technical knowledge, expertise and capabilities (Link, 1988; Grandstrand, Bohlin, Oskarsson, \& Sjoberg, 1992; Chakrabarti, Hauschildt, \& Süverkrüp, 1994; Ahuja \& Katila, 2001; Cloodt, Hagedoorn, \& Van Kranenburg, 2006; Cefis, 2010). Moreover, M\&A by exploiting potential economies of scale and scope (Henderson \& Cockburn, 1996; Chiu, Lai, Lee, \& Liaw, 2008; Cassiman, Colombo, Garrone, \& Veugelers, 2005) can lead to a reduction of both R\&D intensity $^{1}$ and risks (Hitt, Hoskisson, Ireland, \& Harrison, 1991), and solve the problem of organic innovation deficiency (Zhao, 2009). Mainly for these motives, M\&A are a widespread form of company development (Cartwright \& Schoenberg, 2006) and a highly popular phenomenon in the economy, particularly those technology-motivated (Zhao, 2009).

Still, academic and practitioners’ experience highlight that many acquisitions do not succeed in achieving their desired profitability and/or technological objectives, and despite the growing amount of literature on the relationship between M\&A and innovation, and firm performance, the results concerning this area of inquiry fall far short from consensus. Some studies show negative effects (Hitt, Hoskisson, Ireland, \& Harrison, 1991; Ornaghi, 2009; Hall, 1990; Hitt, Hoskisson, Ireland, \& Harrison, 1991; Hitt, Hoskisson, Johnson, \& Moesel, 1996), whilst others find neutral (Prabhu, Chandy, \& Ellis, 2005; Danzon, Epstein, \&

\footnotetext{
${ }^{1}$ The R\&D intensity has been measured as R\&D investment divided by sales and adjusted for average industry R\&D intensity.
} 
Nicholson, 2007; Healy, Palepu, \& Ruback, 1992) or positive impact ${ }^{2}$ (Ahuja \& Katila, 2001; Cloodt, Hagedoorn, \& Van Kranenburg, 2006). Unfortunately, what is observed are generally simple correlations between M\&A activity and innovation input and/or output, and not tested causal links. Moreover, the M\&A and innovation studies are interested in examining the technology-driven deals and their effects on innovation (Ahuja, \& Katila, 2001; Cloodt, Hagedoorn, \& Van Kranenburg, 2006), without offering deeper insight about the joint effect of technological M\&A also on firms’ financial performance.

To better understand these dynamics, this work focuses on two important domains of M\&A performance: the financial domain by examining the market value (Tobin's q) and profitability (ROA), and the non-financial domain by measuring the quality of innovation. In this paper, the term 'quality of innovation' refers to the patent technological performance measured by patent citation-based indicators. A high value of these indicators evidences a high quality of innovation as well. Furthermore, by distinguishing between deals engaged for technological motives and those motivated by other reasons ${ }^{3}$ we analyze the extent to which technological deals affect the quality of inventive output and firm performance in comparison to non-technological M\&A. Our contribution is a better understanding of the real effects and the consequences of engaging in technological M\&A.

In doing so, we focus on the U.S. communication services sector over the period 1998-2005, and our final sample consists of 330 selected deals which involved 162 companies that: 1) acquire at least $50 \%$ of the target shares, 2) have full financial data available from COMPUSTAT database (Standard \& Poor's, 2013) and 3) the acquirer owned at least one own patent before making subsequent acquisitions. The endogeneity issues (e.g. self-selection) raised by previous literature (Maddala, 1983; Shaver, 1998) have been

\footnotetext{
${ }^{2}$ Referring to technological acquisitions.

${ }^{3}$ For example: gaining entry in new markets, obtaining market power, et cetera.
} 
overcome in this work by the adoption matching estimator and propensity score approaches (Rosenbaum \& Rubin, 1983, 1984). These methods are often used in evaluation research to estimate treatment effects in the absence of experimental data. We include in our sample technological M\&A and non-technological M\&A and compare the two groups in term of invention quality results and performance. Our data shows that technological M\&A have a negative effect on the quality of the patenting output but yield positive effects on the economic performance of the acquiring firms involved in the deal.

The paper proceeds as follows. In section II we revise the prior literature and suggest some hypotheses to test. Section III describes the data, the methodology adopted and the results, while section IV discusses the main findings. The final section concludes.

\section{THEORETICAL BACKGROUND AND HYPOTHESES}

\subsection{THE EFFECTS OF TECHNOLOGICAL M\&A ON INNOVATION PERFORMANCE}

Many scholars showed that the key drivers of mergers and acquisitions (M\&A) are primarily attributed to the external technology sourcing and to the exploitation of potential synergies (Andrade, Mitchell, \& Stafford, 2001; Betton, Eckbo, \& Thorburn, 2008; Valentini \& Di Guardo, 2004; Bena \& Li, 2014; De Man \& Duysters, 2005; Inkpen, Sundaran, \& Rockwood, 2000; Kozin \& Young, 1994). In fact, M\&A represent an important component of the firm innovation strategy (Bettis \& Hitt, 1995; King, Covin, \& Hegarty, 2003), through which firms can acquire new technical knowledge, expertise and capabilities (Link, 1988; Grandstrand, Bohlin, Oskarsson, \& Sjoberg, 1992; Chakrabarti, Hauschildt, \& Süverkrüp, 1994; Ahuja \& Katila, 2001; Cloodt, Hagedoorn, \& Van Kranenburg, 2006; Cefis, 2010), and solve the problem of organic innovation deficiency (Zhao, 2009). Moreover, firms by appropriating others' inventive value (Hitt, Harrison, \& Ireland, 2001) can exploit potential 
economies of scale and scope (Henderson \& Cockburn, 1996; Chiu, Lai, Lee, \& Liaw, 2008; Cassiman, Colombo, Garrone, \& Veugelers, 2005) which may lead to a reduction of both R\&D expenditure and risks (Hitt, Hoskisson, Ireland, \& Harrison, 1991).

Villalonga \& McGahan (2005) suggested that firms are more likely to engage in M\&A than in alliances when the technological resources of the target are higher than the bidder's ones. Moreover, Desyllas and Hughes (2009) argued that publicly-trated acquirers who had already produced cutting-edge patents were attracted to target firms having large patent stock. These types of targets are more attractive for their potential to foster greater value creation and more-rapid commercial exploitation of knowledge when acquirer and target are combined (Szucs, 2014). Buying valuable patents allows acquirers to increase the total value of their overall patent portfolio and represents an essential means of gaining access to new technological knowledge which the firm did not formely possess (Gantumur \& Stephen, 2012). In analysis of 1,053 deals involving several technology sectors (e.g., electronic equipment, machinery, computer, telecommunications et cetera), Zhao (2009) argued that technology-motivated M\&A have become a common phenomenon in the U.S. economy, because technological acquisitions are an effective means to gain competitive advantage while responding to the acquiring firm's need for increasing innovation output (Bower, 2001; Ranft \& Lord, 2002).

Ahuja \& Katila (2001)'s investigation of 534 acquisitions in the chemicals sector introduced the distinction between "technological acquisitions" (whose main purpose is technology transfer) and "non-technological acquisitions" (which did not involve the transfer of technology components). Both Ahuja \& Katila (2001) and Cloodt, Hagedoorn \& Van Kranenburg (2006) — which replicated the former's findings in the four additional technology sectors of aerospace and defense, computers and office machinery, pharmaceuticals, and 
electronics and communications equipment—found that technology acquisitions enjoyed higher post-acquisition patent counts. Non-technology acquisitions had no significant effect in Ahuja \& Katila (2001) and exerted a negative effect on the number of post-acquisition patents in Cloodt, Hagedoorn \& Van Kranenburg (2006).

Wagner (2011)'s analysis of 50 large U.S. semiconductor firms, sought evidence of exploratory versus exploitative innovation when measuring the differential effects between technology-related acquisitions and non-technological acquisitions. Results were consistent with that reported by Hagedoorn and Duysters (2002) and subsequently by Desyllas and Hughes (2008), and showed the technology-related acquisitions ${ }^{4}$ were positively associated with inventive output, while non-technological acquisitions negatively affect the inventive output (in terms of patent counts).

All these contributions seem to agree that technological M\&A positively affect the quantity of inventive output while non-technological M\&A are non-significantly or even negatively related. However, the quantity of patent counts -as showed by Griliches (1990)can not be considered a reliable proxy of patent importance, being the value of a patent portfolio often concentrated in few patents. In addition, patent citations by reflecting the invention attracting power, represent a meaningful measure of the technological quality and innovation performance (Harhoff, Narin, Scherer, \& Vopel, 1999).

Recently, Valentini (2012), by examining a sample of 159 deals in the U.S. 'medical devices and photographic equipment' industry, investigated on the effects of M\&A not only on the quantity but also on the quality of the post-deal innovation performance. He used the three main indicators of the patent quality introduced by Trajtenberg, Henderson and Jaffe (1997) and then resumed by Hall, Jaffe, \& Trajtenberg (2001): impact, generality and

\footnotetext{
${ }^{4}$ Wagner focused on the number of technological-related and non-technological acquisitions.
} 
originality. The main findings regarded the positive relationship between M\&A and patent quantity -probably influenced by the pressure for performance- and the negative impact of M\&A on all the three quality patent measures.

The results of Valentini (2012) can be also explained using the concepts of exploration and exploitation introduced by March (1991). Exploration involves the search for broader and newer knowledge, whilst exploitation involves the refinement and deepening of the extant knowledge. As showed by Le, Park, and Kroll (2014), acquirers benefit more in terms of innovation performance from the post-deal $R \& D$ exploitation rather than exploration. This means that the $R \& D$ efforts after the acquisitions will contribute to a significant increase of the inventive output (i.e. patents).

Moreover, the acquirement of external knowledge - according to existing literature- is perceived to foster the breakthrough innovations (Ahuja \& Katila, 2001; Almeida \& Phene, 2004; Phene, Flamoe-Lindquist, \& Marsh, 2006; Phene \& Almeida,2008; Rosenkopf \& Nerkar, 2001; Bapuji, Loree, \& Crossan, 2011). In presence of these high value inventions, firms often use patents for strategic aims by creating the so called "defensive blockades" which consist in the enlargement of the acquirer's "manoeuvring space" to avoid litigation (Blind, Cremers, \& Mueller, 2009; Blind, Edler, Frietsch, \& Schmoch, 2006; Cohen, Goto, Nagata, Nelson, \& Walsh, 2002; Kingston, 2001; Andries \& Faems, 2013). This strategy, inetavibly will increase the breakthrough patent protection as well as the number of patents issued. Hence, there will be a further emphasis of the rise in quantity at expense of the quality of patent output.

These dynamics, will not involve the non-technological acquisitions which being driven by other reasons, will focus on the achievement of other goals different from technological ones: i.e. entering desirable market (Brakman, Garretsen, \& Van Marrewijk, 
2013; Chevalier, 2004), integrate vertically/horizontally (De Man \& Duysters, 2005), gain market power (Anand \& Singh, 1997; Baker \& Bresnahan, 1985; Barton \& Sherman, 1984), diversification (Berger \& Ofek, 1995) etc..

In summary, according to the existing literature we would expect that firms involved in technological M\&A while experience an increase of the quantity of inventive output particularly due to R\&D activity exploitation adopted by the acquirer and "defensive blockade" strategies - lose out a decrease of the average quality of patents, performing worse than firms engaged in non-technological deals which may have no significant improvement or even higher patent quality performance.

Hypothesis 1a: Technological M\&A have a negative effect on the quality of the postdeal inventive output.

Hypothesis $1 b$ : The firms involved in technological M\&A have a lower quality of the post-deal inventive output in comparison to those engaged in non-technological M\&A.

\subsection{THE EFFECTS OF TECHNOLOGICAL M\&A ON FIRM PERFORMANCE}

Though the effects of M\&A on firm performance have been broadly examined in literature, they still show controversial results. Many scholars pointed out that M\&A have a negative effect on firm performance or even destroy acquirers’ market value (Hitt, Harrison, \& Ireland, 2001; Agrawal, Jaffe, \& Mandelker,1992; Rau \& Vermaelen, 1998; Antoniou, Petmezas, \& Zhao, 2007; Sudarsanam \& Mahate, 2003), while others (see Healy, Palepu, \& Ruback, 1992) demonstrated that the merged firms significantly improved their performance due to the realization of higher post-deal cash flows.

Moreover, as prior studies on innovation found evidence about the strong relationship between R\&D activities (input/output) and market value (see Toivonen, Stoneman, \& 
Bosworth, 2002) the M\&A literature was further stimulated on investigating how technological M\&A could be used to enhance the firms’ R\&D in order to positively affect the firm market value (Kallunki, Pyykkö, \& Laamanen, 2009). In particular, many contributions recognize that technology M\&A are beneficial for the acquired firm (Higgins \& Rodriguez, 2006; Kohers \& Kohers, 2000; Conn, Cosh, Guest, \& Hughes, 2005).

In addition, Kallunki, Pyykkö and Laamanen (2009), showed that when the deal involved two technology companies, there was a very high increase on the stock price magnitude, even $107 \%$ in the year the M\&A occurred. These results were not observed in the case of non-technology targets primarily due to the potential lack in the target's absorptive capacity (Cohen \& Levinthal, 1990; Higgins \& Rodriguez, 2006) which may negatively affect the R\&D activity and the profitability.

To better understand what a “technology acquisition” is meant, Hung and Tang (2008) provided a definition according to which the technological M\&A is "a process of planned, selective, focalized importation of advanced technology which the enterprise has not nor did not master, and new application of imported technology which can bring expectant economic benefits to new users” (p:551). This definition suggests that the importation of the advanced technologies represents a precious inputs for the $R \& D$ activities which if synergistically exploited, are expected to positively affect the innovation output and market value. Hence, the analysis about the effects of the technology M\&A inevitably is connected with the value of the intangible assets represented by patents and their relationship with both productivity and market value.

Patents counts being considered as an important measure of both technological performance and R\&D outcomes (Stock \& Stock 2006; Chen \&Chang 2012; Chen, Shih, \& Chang 2014) are showed to be positively related to the market value of the patent portfolio 
(Hall, Jaffe, \& Trajtenberg, 2005). Chen and Chang (2010), by analyzing the U.S. pharmaceutical industry, found that portfolios with high patent counts had higher market value in comparison to smaller portfolios. Hence, a main objective for firms engaged in technology M\&A is the increase in the number of patent issued.

Moreover, Blind, Edler, Frietsch, and Schmoch (2006), investigating on the motives to patent, observed "new strategic" ones like those used to signal potential investors about inventions which were not embodied in any commercialized good. This finding suggests us that an increase in the number of the patented invention can be used to stimulate and influence the market's expectations. In addition, the expert ratings are influenced by the size of the patent portfolio (patent counts) and not by the quality and impact of the innovation output (Narin, Noma, \& Perry, 1987).

Bloom and Van Reenen (2002) - finding that inventive output has an economically and statistically significant effect on firm productivity and market value- suggested that patents immediately affect the market value, while productivity takes more time. An explanation can be led to the lag between the invention and the product commercialization. Moreover, Meeks and Meeks (1981) showed that respect to other profitability post-deal measures, ROA was less sensitive to distortion caused by the M\&A transaction, hence we expect that technology M\&A will be influenced more by an indicator related to the market value (i.e. Tobin's q).

Finally, as the literature suggests, technological M\&A are expected to have better performance in terms of both market value and productivity. However, we expect that the Tobin's q will be highly influenced by the increase in the number of patents granted after the deal- rather than patent quality- as a signal of the synergy generation among the firms involved. 
Hypothesis 2: Firms involved in technological M\&A will have better post-deal economic performance in comparison to firms engaged in non-technological M\&A, particularly for Tobin’s q.

\section{METHOD}

In this paper, we apply a multivariate matching method to assess the effects of the technological M\&A on inventive output and firm performance. In the last decade, the matching estimator method is gaining success in different fields, including economics and more recently management (see the work of Valentini, 2012). The key feature of this method is its approximation to a randomized ex post experiment, when experimental data are absent (Heckman, Ichimura, \& Todd, 1998; Heckman \& Navarro-Lozano, 2004). The basic idea is to compare the results obtained by a treated group with those obtained by "twins" in the control group. Both groups share a set of characteristics/indices $\left(\mathrm{X}_{i}\right)$, but they obviously differ in the treatment variable. A common estimand in non-experimental studies is the "average effect of the treatment on the treated" (ATT), which considers the effect for observed units included in the treatment group.

Following the Abadie, Drukker, Herr, and Imbens (2001), and Abadie and Imbens (2002) method, let formalize that each firm engaged in an M\&A has two potential outcomes $Y_{i}(1)$ if involved in a technological deal and $Y_{i}(0)$ if it is not. Using a dummy variable $T_{i}$, we denote $T_{i}=1$ if the firm receives the treatment, signaled by a positive difference in terms of patent counts before and after the M\&A took place, and $T_{i}=0$ for the control group. $Y_{i 1}$ denotes the value of unit $i$ if the firm had a tangible technological improvement after the deal measured by an increase in the number of patents, whilst $\mathrm{Y}_{i 0}$ refers to the value of unit $i$ if the supposed motive of the deal was not technological, or if the aim of an eventual technological M\&A has not been achieved. If the technological benefit for each firm could be observable it would be summarized as $Y_{i}(1)-Y_{i}(0)$ and the average treatment effect of the 
treated population should be $\tau_{A T T}=\mathrm{E}(\tau \mid \mathrm{T}=1)=\mathrm{E}[\mathrm{Y}(1) \mid \mathrm{T}=1]-\mathrm{E}[\mathrm{Y}(0) \mid \mathrm{T}=1]$. The main issue is that both these outcomes are not observable at the same time, this means that there is only one counterfactual outcome observable and it refers to the treated group, whilst $\mathrm{E}[\mathrm{Y}(0) \mid \mathrm{T}=1]$ is impossible to estimate. Therefore, we can use the simple matching estimator of the ATT, which is defined as the difference between expected outcomes with or without treatment, and it is given by: $\tau=\frac{1}{N} \sum_{i: T=1}(\mathrm{Y} i-\hat{Y} i(0))$, when $\mathrm{N}$ is the number of deals. Consistently with the method suggested by Abadie \& Imbens (2002) and Villalonga (2004), in order to reduce bias and produce matches of higher quality, we apply a matching estimator with replacement and four comparison. Specifically, we use the propensity score matching (Rosenbaum and Rubin 1983) based on logistic regression, where $\mathrm{Y}$ is conditioned on $\mathrm{X}$ by matching on the probability of assignment to treatment, the so-called propensity score. Usually, as sample size grows large, matching on the propensity score produces balance on the vector of covariates $\mathrm{X}$ (Rosenbaum and Rubin 1983). Propensity score matching involves matching each treated unit to the nearest control unit on the unidimensional metric of the propensity score vector.

Following previous studies, we choose to use the following matching covariates: logarithm of assets, productivity, size, leverage, intangible assets and year dummies. The propensity score is estimated through a logistic regression model in which the treatment variable plays the role of response while the control variables (matching covariates) the role of predictors. Next, observations are matched on the basis of the estimated propensity score. In order to make matching outcomes more, the procedure is repeated on 1,000 bootstrap samples. Bootstrapping is highly recommended because the bootstrapped KolmogorovSmirnov test, unlike the standard test, provides correct coverage even when there are point masses in the distributions being compared (Abadie, 2002). 
We used matching with replacement in the estimation of the average treatment effect. Results of computations run on different settings show that matching each treatment unit with the 4 closest controls allows us to balance the bias: variance trade-off induced by the possible increase in bias obtained when selecting multiple controls for each treated individual and the possible decrease in variance deriving from larger matched sample size.

Finally, our hypothesis have been tested using an alternative of the parametric T-test: the nonparametric Wilcoxon Signed Ranks Test (Corder \& Foreman,2009). The latter pertains to the comparison of two samples which are paired, or related (Wilcoxon, 1945) and it is more indicated to be used in statistics when for a given even, the assumptions ${ }^{5}$ of the ttest are not met by the data.

\subsection{DATA SOURCE}

In the last decades, the U.S. communication services sector has experienced several M\&A waves due to both technology shocks and deregulation (Gantumur \& Stephan, 2012; Harford, 2005). We focus our study on this industry for several reasons. First, the high number of M\&A transactions: over the period 1998-2005-according to Thomson Reuters (2013), Thomson One’s Mergers \& Acquisitions (2013), SDC Platinum Database (2013) there occurred 2028 deals which involved $928^{6}$ different U.S. communication companies. Second, the increasing demand for new technologies and the declining demand environment for older ones (Christensen, 1997; Harrigan, 2003). Third, the fundamental role of the intellectual property protection and the high-density of the patenting activity (Hall \& Ziedonis, 2001; Ziedonis, 2004). Last, the survival importance of the constant innovation improvement due to the high market competition (Danguy, de Rassenfosse, \& van

\footnotetext{
${ }^{5}$ An assumption of the paired t-test is that the data measured on a specific interval are distributed following a normal distribution.

${ }^{6}$ These firms acquired at least half of the total shares of the target firm.
} 
Pottelsberghe de la Potterie, 2013). These particular features, make this sector highly suitable to analyze the effects of M\&A on inventive output (patents) and economic performance.

We first identified 361 deals over the period 1998-2005 which involved 162 companies that: 1) acquire at least $50 \%$ of the target shares, 2) have full financial data available from COMPUSTAT database (Standard \& Poor's, 2013) and 3) the acquirer owned at least one own patent before making subsequent acquisitions. As many companies engaged in several acquisitions in a single year, we further reduced our sample -controlling for the number of deals per year for each firm- by selecting 330 deals. 120.588 U.S. patents granted over the period 1995-2009 - consistently to a four-year window- and their patent backward and forward citations rising up the sample to a total of $3,686,084$ citations. The patent information were available from the Derwent Innovation Index database (2013).

A four-year window (Sampson, 2007) was chosen to take into account the lack of forward citations in more recent years. Hall, Jaffe \& Trajtenberg (2005) observed that it is necessary several time before the patent accumulates significant information in terms of forward citations. Also, Mehta, Rysman \& Simcoe (2010) showed empirically that the "citation clock" does not start in correspondence to the date in which the patent is granted, but it takes more time. In fact, patents granted recently have very few or even no citing patents.

We measure three patent dimensions (impact, breadth and depth) as innovation quality proxies (Fleming, 2001; Trajtenberg, Henderson, \& Jaffe, 1997; Argyres \& Silverman, 2004; Hall \& Ziedonis, 2001; Hall, Jaffe, \& Trajtenberg, 2001; Trajtenberg, 1990; Valentini \& Di Guardo, 2012). We examined patent-quality patterns using U.S.-granted patents and the parsimonious 36-category system of Hall, Jaffe, \& Trajtenberg (2001) which 
is derived from the USPTO classification schema. Our patent-quality indicators-- generality and originality--were calculated using their arithmetic weighting indices.

\subsection{MATCHING VARIABLES AND TREATMENT}

The matching estimator method requires several control variables to better match the treated firms with their "twins" in the non-treated group, allowing us to measure the real effects of the treatment itself. In our study, the treatment consists in engaging in a technological M\&A, whereas the control firms do not. We can assume that among the many M\&A- in which the firms of our sample are involved- some of them are specifically technological driven. In the light of previous studies, we can further assume that the M\&A characterized by an increase in the number of patents granted, are the ones technological driven (the treatment group) and the others with no increase or a decrease in the patent counts, are the control group (i.e. the deal of firm A is considered technology-driven if the number of patents in the four-year window after the deal is higher than the number of patent counts in the pre-deal window, otherwise the deal is considered non-technological). In this way, we can observe if the treatment group experience a better or a worse outcome in terms of patents quality (impact, generality and originality) and in terms of economic performance.

Consistently with previous works we select the following covariates: logarithm of assets, productivity, size, leverage, intangible assets, year dummies and number of acquisitions made by a firm in each considered year. Firm productivity: we use the sales-peremployee ratio which represents an indicator of the productivity of employee. Firm Size: we

control for the asset-per employee ratio as a measure of capital intensity. Firm leverage is represented by long-term debt to total assets (Hitt, Hoskisson, Ireland, \& Harrison, 1991; Barkema \& Schijven, 2008). The intangible assets are represented by the proportion of the intangibles respect to total assets. This is an indicator of the potential existing patents in the 
firm patent portfolio. Year dummies: we consider a dummy variable for each sampling year as the acquisition year may influence the post-deal performance, recognizing that in particular the U.S. communication sector was subject to several acquisition waves (Gantumur \& Stephan, 2012; Harford, 2005). In our sample, many firms engage in several M\&A, we control for the number of the acquisitions made in a single year, in order to take into account the influence of the low or high occurrence of this organizational event.

\subsection{INNOVATION PERFORMANCE}

In order to fully appreciate the post-deal innovation performance we examine the changes in the quality of the acquirer patent portfolio. The literature suggests several measures based on both R\&D input and output. De Man \& Duyster (2005) in an M\&A review suggest that input indicators may lead to misleading results: M\&A by reducing the $R \& D$ redundancies can decrease the $R \& D$ expenditure but not necessarily impoverishes the firm innovativeness. For this reason we adopt the output perspective to better capture the firm's inventive capabilities (Hall, Jaffe, \& Trajtenbrg, 2005; Ahuja \& Katila, 2001; Valentini, 2012).

A reliable measure of innovation importance and quality is represented by citationbased indicators (Griliches, 1990; Bloom \& Van Reenen, 2002; Yayavaram \& Ahuja, 2008). In particular, those based in forward citations represent the "lifeblood" of technological development (Tseng, Hsieh, Peng, \& Chu, 2011).

\subsubsection{Impact index: Citations received by subsequent patents}

The impact index is a measure of the total number of citations received by subsequent patents, and reflects the technological influence of a patent in further inventions. Forward citations are considered to be more directly related to innovation importance (Lanjouw \& 
Schankerman, 2004), as higher is the number of citations, higher will be its technological impact on subsequent patented innovations (Hall, Jaffe, \& Trajtenberg, 2001).

We measured the difference between pre-deal and post-deal portfolio impact. Generally, indicators based on forward citation are highly influenced by time. If two patents have identical features but different application date, the patent with the latest date has a lower probability to receive citations. Therefore, it is important to normalize citation-based indexes in order to allow the comparison between periods. We used the average value of the measure itself and the average of the sector for each examined year.

\subsubsection{Generality: Breadth of innovation}

The generality index is a measure of the breadth of applicability of a technology on subsequent inventions and it is based on the classification codes of the forward citations. When the breadth is high, it means that the knowledge embodied in the patent is used in several technological domains, hence the invention is considered "general". The generality index, was first introduced by Trajtenberg, Henderson and Jaffe (1997) and then resumed by Hall, Jaffe, \& Trajtenberg. (2001). It can be represented as:

$$
\text { Generality }_{i}=1-\sum_{j=1}^{n_{i}} t_{i j}^{2}
$$

where $t_{i j}$ indicates the percentage of citations received by patent $t_{\mathrm{i}}$ that belong to patent class $\mathrm{s}_{\mathrm{j}}$,

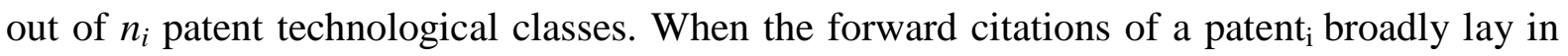
several technology classification, this measure will be high, otherwise it will be low or even equal to zero in the case in which all the citing patents share the same classification code. Briefly, a high generality score suggests that a patent had an impact that influenced subsequent innovations in a widespread variety of technological fields. 
We measured two generality indicators - four years before and four years after the acquisition. Similarly, to the impact index, generality has been normalized by the sector average in each year and its own average in the four-year window.

\subsubsection{Originality Indicator: Depth of innovation}

The Originality indicator measures the depth of the technological knowledge bases synthetized in a patent application. This index is known to capture the historical aspects of the technology embodied in the patent data which by taking into account the classification codes of the backward citations can be expressed as follows (Trajtenberg, Henderson and Jaffe,1997; Hall, Jaffe, \& Trajtenberg, 2001):

$$
\text { Originality }_{i}=1-\sum_{j=1}^{n_{i}} s_{i j}^{2}
$$

$\mathrm{S}_{\mathrm{ij}}$ represents the forward citations of patent $\mathrm{i}$ (expressed in percentage terms) that have class code $\mathrm{j}$, out of $n_{\mathrm{i}}$ patent technology classes. Hence, if an invention is built on many different technologies, it is considered to be more "original" than those which lie on a single technological domain. The value of originality will rise as the number of technological classification codes of is going to be broader.

By measuring pre- and post-acquisition originality indexes, we evaluated the changes that might occur before and after an acquisition engagement.

\subsection{FINANCIAL PERFORMANCE}

In order to capture more information about the impact of M\&A on firm performance, we used two types of indicators: an asset-stewardship measure (Return on Assets) and Tobin's q. ROA was measured as EBITDA divided by total assets to recognize that some portion of short-term profits had been invested in longer-lived assets that were used in 
operations (Hoskisson \& Hitt, 1990; Hitt, Harrison, Ireland, \& Best, 1998; Zollo \& Singh, 2004; Barkema \& Schijven, 2008). Meeks and Meeks (1981) showed that respect to other profitability post-deal measures, ROA was less sensitive to distortion.

Tobins'q is a market performance measure, which reflects investors' expectations regarding the future cash flows that would be generated as well as the market's expectation about intangible assets (Patel \& Ward, 2011; Sandner \& Block, 2011; Hall, Jaffe, \& Trajtenberg, 2005). During the stock market run-up that is associated with the Internet bubble, firms booked accounting losses that resulted in negative equity values on their balance sheets even as their market valuations soared. Following Gompers, Ishii, Metrick (2003), Tobin's Q for the four years after an acquisition occurred was calculated as the market value of assets divided by the book value of assets, where the market value of assets is computed as book value of assets plus the market value of common stock less the sum of the book value of common stock and balance sheet deferred taxes. All book values for fiscal year $_{t}$ and years thereafter (obtained from COMPUSTAT) were combined with the market value of common equity at the calendar end of year ${ }_{t}$-- and for years ${ }_{t+i}$ thereafter (where $_{i}=1$, $2,3,4)$

\section{RESULTS}

This study analyzed 330 deals in the U.S. communication services sector and investigated on how better/worse firms involved in a technological M\&A perform, in comparison to other companies which engaged in an M\&A for other motives. Three patent quality indicators - impact, generality and originality- and two firm performance measures Tobin's $q$ and ROA- have been assessed to better understand the overall dynamics of the organizational “shock” caused by M\&A. 
The endogeneity issues have been considered by applying an effective and increasingly popular approach in innovation studies: the matching estimator method which uses the average treatment in the treated for the estimation of the phenomenon. This statistical tool allow us to compare and determine the differences between twins of firms (treated and control) which present only a dissimilarity, the treatment. As argued previously, firms involved in technological M\&A (treated group) are identified by the increase in the number of patents after the deal was consummated - as a direct consequence of the firm willingness to use M\&A as a tool for technology acquirements - while firms engaged in nontechnological M\&A (non-treated/control group) will not.

Table 1 reports the average post-deal effects of M\&A on innovation performance in each of the two M\&A groups: technological and non-technological. The impact and the generality indicators have been normalized - as explained in the paragraphs 3.3.1 and 3.3.2.- whilst originality is not affected by time, hence it doesn’t need normalization.

\begin{tabular}{|c|c|c|}
\hline Patent Quality indicator & Technological M\&A & Non-Technological M\&A \\
\hline Impact & $-61.36 * * *$ & $45.50 * * *$ \\
\hline Generality & $-0.03 \dagger$ & $0.01 \dagger$ \\
\hline Originality & $-0.01 * * *$ & $0.03^{* * *}$ \\
\hline $\begin{array}{l}\text { Matching Covariates } \\
\text { logarithm of assets } \\
\text { productivity } \\
\text { size }\end{array}$ & & $\begin{array}{l}\text { Leverage } \\
\text { Intangible assets } \\
\text { Year dummies } \\
\text { Number of acquisitions per year }\end{array}$ \\
\hline$* * * \mathbf{p}<0.01 \quad * * \mathbf{p}<0.05 \quad * \mathbf{p}<0.10 \quad+\mathbf{p}>0.10$ & & \\
\hline
\end{tabular}

Table 1: Average effects on the post-deal innovation performance for technological and non-technological M\&A.

As expected, all patent quality indicators are negative for technological deals signaling a decrease in the post-deal innovation performance, and confirming our Hypothesis 1a. In particular, the impact index, which captures and highlights the importance of a patent 
in terms of forward citations, sharply drops down with high statistical significance. This means that after a technological deal the firm's patent portfolio receives in average less citations. This result may be influenced by the aim of the bidder to increase the number of patents -in order to fully exploit the target technological potential, or to provide to the high value acquired patents a wider protection by blocking competitors in that specific technological domain ${ }^{7}$ - causing inevitably an impoverishment of the average.

The generality index is a measure of the breadth of the patent technology embodied in subsequent applications, it shows a decrease, though it is not statistically significant. Hence, it clearly emerges that the patent portfolio loses its appeal in broader technological fields. Moreover, the originality is statistically significant and worsens after a technological deal, though slightly less than the other indicators. This can be interpreted as a further confirmation of the fact that firms involved in technological deals increase their technological output in a narrower range of technological classification codes, probably around the high technology acquired patents granted after the deal.

As Table 1 shows, the patent quality of the firms involved in non-technological M\&A even enjoy the positive effects of the deal, being all the indicators positive and statistically significant, except the generality index. Hence, we can affirm that firms involved in technological M\&A have a lower quality of the post-deal inventive output in comparison to those engaged in non-technological M\&A, confirming our Hypothesis $1 b$.

Table 2 shows the post-deal average effects on the firm performance for technological and non-technological $M \& A$ in each post-deal year (i.e. with $\mathrm{t}_{1}$ we denote the first year after the deal was consummated).

\footnotetext{
${ }^{7}$ The so called "Defensive Blockades".
} 


\begin{tabular}{lcccc}
\hline Tobin's $q$ & $\mathbf{t}_{\mathbf{1}}$ & $\mathbf{t}_{\mathbf{2}}$ & $\mathbf{t}_{\mathbf{3}}$ & $\mathbf{t}_{\mathbf{4}}$ \\
\hline Technological M\&A & $1.63^{* * *}$ & $1.30^{* *}$ & $1.33 \dagger$ & $1.46^{* * *}$ \\
Non-Technological M\&A & $1.21^{* * *}$ & $1.18^{* *}$ & $1.54 \dagger$ & $1.29^{* * *}$ \\
\hline \hline Return on Assets (ROA) & $\mathbf{t}_{\mathbf{1}}$ & $\mathbf{t}_{\mathbf{2}}$ & $\mathbf{t}_{\mathbf{3}}$ & $\mathbf{t}_{\mathbf{4}}$ \\
\hline Technological M\&A & $0.06^{* *}$ & $0.06 \dagger$ & $0.07^{* *}$ & $0.05 \dagger$ \\
Non-Technological M\&A & $0.06^{* *}$ & $0.06 \dagger$ & $0.09^{* *}$ & $0.07 \dagger$ \\
\hline
\end{tabular}

Table 2: Average post-deal effects on firm performance for technological and non-technological M\&A.

Tobin's Q is a widespread measure in economic studies and reflects the investors' expectations regarding the future cash flows that will be generated by the merged firm. As Table 2 clearly reports, the post-deal firm performance for all M\&A is positive in all the periods observed, though they lose statistical significance in correspondence with to ' $t_{3}$ ' for Tobins' $q$ and ' $t_{2}$ ' and ' $t_{4}$ ' for ROA.

In particular, the Tobin's q of the firms involved in a technological M\&A in the four years after the deal, improves and it is higher than the non-technological M\&A. This means that when the R\&D efforts are synthetized in an increase of the inventive output (patents), the market overestimates the firm's potential and expects future rent extraction. This is a further confirmation of the high press for performance faced by firms which engage in technological M\&A to stimulate the firm market value. In addition, the market seems not to be able to fully appreciate the patent quality as it is significantly worsened.

ROA, which is measured as EBITDA divided by total assets, being less sensitive to distortion caused by the M\&A transaction follow a similar trend in both technological and non-technological deals, even with better and significant results for the non-technological group in $t_{3}$. This confirms our Hypothesis 2. 


\section{CONCLUSIONS}

This study examined the effects of technological M\&A on both innovation and firm performance, and further investigated on the motives that push bidders to acquire external knowledge through M\&A. In particular, we focused on three dimensions of the quality of the inventive output - impact, breadth and depth of innovation- measuring three quality indicators: impact, generality and originality (Fleming, 2001; Trajtenberg, Henderson, \& Jaffe, 1997; Argyres \& Silverman, 2004; Hall \& Ziedonis, 2001; Hall, Jaffe, \& Trajtenberg, 2001; Trajtenberg, 1990; Valentini \& Di Guardo, 2012).

In the light of earlier works (Ahuja \& Katila; Cloodt, Hagedoorn, \& Van Kranenburg, 2006) we argued that technological M\&A lead to an increase of the inventive output in terms of patent counts. We adressed two main reasons: the first, the strategy of R\&D activity exploitation adopted by the acquirer, as suggested by the findings of Le, Park, and Kroll (2014), and the so called "defensive blockades" which consist in the enlargement of the acquirer's "manoeuvring space" around strategic and high value patents (Blind, Cremers, \& Mueller, 2009; Blind, Edler, Frietsch, \& Schmoch, 2006; Cohen, Goto, Nagata, Nelson, \& Walsh, 2002; Kingston, 2001; Andries \& Faems, 2013).

Our sample consists of 330 deals which involved 162 companies of the U.S. communication services sector. We used the matching estimator and propensity score methods to take into account the endogeneity issues (Maddala, 1983; Shaver, 1998) and to better allow the comparison between technological and non-technological M\&A (Rosenbaum \& Rubin, 1983, 1984).

Our empirical results showed that firms engaged in technological M\&A had lower innovation performance -in comparison to firms involved in non-technological deals- as reflected by a statistically significant decrease of the average quality of the inventive output, 
captured by citation-based patent analysis. These findings are consistent with the work of Valentini (2012) who demonstrated that an indirect post-deal effect of an increase of the inventive-output, is the decrease of the patent quality. Hence, clearly emerged that the postdeal increase of the quantity is done at expense of the quality, for technological M\&A. However, the firms engaged in non-technological M\&A do not suffer the high technological pressure for performance, and as we supposed, they present even better results compared to the companies involved in technological M\&A.

Furthermore, in order to deeper understand the motives why firms continue using technological M\&A as a means to acquire external knowledge, though this leads - as argued above- an impoverishing of the patent quality, we focused our attention on the analysis of the financial domain by using two indicators: Tobin's $q$ which better reflects the market expectations for future cash flows and the Return on Assets (ROA) which is less influenced by the bargaining of the acquisition (Meeks \& Meeks, 1981).

This study showed that firms which were involved in technological M\&A had higher post-deal financial performance, compared to those non-technological, particularly for the Tobin's q. This means that the market overestimates the increase of the number of patents - as in the case technological deals- though they present a lower average quality. However, the return on assets (ROA) resulted less sensitive though it marked a positive difference between the two deal types considered till the third year after the deal. This result suggests that the beneficial effects of the technological M\&A last for few years. Maybe, this is a reason why many firms strategically choose to continuously acquire innovate targets.

Our findings, first contributed to the innovation literature, shedding more light on the effects of the technological M\&A on the quality of innovation performance. We found empirical support about the beneficial effect of technological M\&A on the acquirer's firm 
(Higgins \& Rodriguez, 2006; Kohers \& Kohers, 2000; Conn, Cosh, Guest, \& Hughes, 2005), contributing to the M\&A literature.

The managerial implication suggested by this study can be summarized as follows: managers of firms involved in technological M\&A should know that the innovation embodied in their patent portfolio may be overestimated and may not reflect the effective value measurable through a broadly used and acceptable citation-based indicators. Moreover, investors and the market more in general should be more aware about the quality of the patents granted and try to understand when acquirers actually adopt the strategic "defensive blockade”, without adding much value to the patent portfolio and intangible assets.

Finally, this work used the Hall, Trajtenberg and Jaffe (2001) indicators based on US classification codes. It should be said that $\mathrm{USPTO}^{8}$ is exclusively adopting the Cooperative Patent Classification, a new patent classification shared with $\mathrm{EPO}^{9}$. This means that there is a need to build new and as hoped better patent indicators. Hence, further research may focus not only on other sectors but may also use novel and more dynamic indicators - for instance those proposed by Harrigan, Di Guardo and Velez (2014) which are based on Derwent Patent Classification.

\section{REFERENCES}

Abadie, A. (2002). Bootstrap tests for distributional treatment effects in instrumental variable models. Journal of the American Statistical Association, 97: 284-292.

Abadie, A., \& Imbens, G. (2002). Simple and bias-corrected matching estimators for average treatment effects. Cambridge, MA: National Bureau of Economic Research.

\footnotetext{
${ }^{8}$ U.S. Patent Office.

${ }^{9}$ European Patent Office.
} 
Abadie, A., Drukker, D., Herr, J., \& Imbens, G. (2001). Implementing matching estimators for average treatment in Stata. Stata Journal, 1(1):1-18.

Agrawal, A., Jaffe, J., \& Mandelker, G. (1992). The post-merger performance of acquiring firms: a re-examination of an anomaly. Journal of Finance, 47(4): 1605-1621.

Ahuja, G., \& Katila, R. (2001). Technological acquisitions and the innovation performance of acquiring firms: a longitudinal study. Strategic Management Journal, 22: 197-220.

Almeida, P., \& Phene, A. (2004). Subsidiaries and knowledge creation: the influence of the MNC and host country on innovation. Strategic Management Journal, 25: 847-864.

Anand, J., \& Singh, H. (1997). Asset redeployment, acquisitions and corporate strategy in declining industries. Strategic Management Journal, 18: 99-118.

Andrade, G., Mitchell, M., \& Stafford, E. (2001). New evidence and perspectives on mergers. Journal of Economic Perspectives, 15: 103-120.

Andries, P., \& Faems, D. (2013). Patenting activities and firm performance: Does the size matters? Journal of Product Innovation Management, 30(6): 1089-1098.

Antoniou, A., Petmezas, D., \& Zhao, H. (2007). Bidders gains and losses of firms involved in many acquisitions. Journal of Business Finance \& Accounting, 34: 1221-1244.

Argyres, N., \& Silverman, B. (2004). R\&D, organization structure, and the development of corporate technological knowledge. Strategic Management Journal, 25: 929-958.

Baker, J., \& Bresnahan, T. (1985). The gains from merger or collusion in productdifferentiated industries. The Journal of Industrial Economics, 33(4): 427-444.

Bapuji, H., Loree, D., \& Crossan, M. (2011). Connecting external knowledge usage and firm performance: An empirical analysis. Journal of Engineering and Technology Management, 28: 215-231.

Barkema, H., \& Schijven, M. (2008). How do firms learn to make acquisitions? A review of past research and agenda for the future. Journal of Management, 34(3): 594-634.

Barton, D., \& Sherman, R. (1984). The price and profit effects of horizontal mergers: a case study. The Journal of Industrial Economics, 33(2): 165-177. 
Bena, J., \& Li, K. (2014). Corporate innovations and mergers and acquisitions. The Journal of Finance, 69(5): 1923-1960.

Berger, P., \& Ofek, E. (1995). Diversification's effect on firm value. Journal of Financial Economics, 37(1): 39-65.

Bettis, R., \& Hitt, M. (1995). The new competitive landscape. Strategic Management Journal, 16: 7-19.

Betton, S., Eckbo, B., \& Thorburn, K. (2008). Corporate takeovers. In B. Eckbo, Handbook of Corporate Finance: Empirical Corporate Finance. North-Holland, Amsterdam the Netherlands: Elsevier.

Blind, K., Cremers, K., \& Mueller, E. (2009). The influence of strategic patenting on companies' patent portfolios. Research Policy, 38: 428-436.

Blind, K., Edler, J., Frietsch, R., \& Schmoch, U. (2006). Motives to patent: Evidence from Germany. Research Policy, 35(5): 655-672.

Bloom, N., \& Van Reenen, J. (2002). Patents, real oprions and firm performance. The Economic Journal, 112 (March): C97-C116.

Bower, J. (2001). Not all M\&As are alike -- and that matters. Harvard Business Review, 79(3): 93-101.

Brakman, S., Garretsen, H., \& Van Marrewijk, C. (2013). Cross-border acquisition activity and revealed comparative advantage. Journal of Economics and Management Strategy, 28-57.

Cartwright, S., \& Schoenberg, R. (2006). Thirty years of mergers and acquisitions research: Recent advances and future opportunities. British Journal of Management, 17: S1-S5.

Cassiman, B., Colombo, M., Garrone, P., \& Veugelers, R. (2005). The impact of M\&A on the R\&D process: an empirical analysis of the role of technological, and marketrelatedness. Research Policy, 34: 195-220.

Cefis, E. (2010). The impact of M\&A on technology sourcing strategies. Industry and Innovation, 19: 27-51. 
Chakrabarti, A., Hauschildt, J., \& Süverkrüp, C. (1994). Does it pay to acquire technological firms? R\&D Management, 24(1): 47-56.

Chen, Y., \& Chang, K. (2010). The relationship between a firm's patent quality and its market value -- The case of US pharmaceutical industry. Technological Forecasting \& Social Change, 77: 20-33.

Chen, Y., \& Chang, K. (2012). Using the entropy-based patent measure to explore the influences of related and unrelated technological diversification upon technological competences and firm performance. Scientometrics, 90 (3): 825-841.

Chen, Y., Shih, C., \& Chang, C. (2014). Explore the new relationship between patents and market value: a panel smooth transition regression (PSTR) approach. Scientometrics, 98: $1145-1159$.

Chevalier, J. (2004). What do we know about cross-subsidization? Evidence from merging firms. Advances in Economic Analysis \& Policy, 4(1).

Chiu, Y., Lai, H., Lee, T., \& Liaw, Y. (2008). Technological diversification, complementary assets, and performance. Technological Forecasting \& Social Change, 75: 875-892.

Christensen, C. (1997). The Innovator's Dilemma: When New Technologies Cause Great Firms Fail. Harvard Business Press.

Cloodt, M., Hagedoorn, J., \& Van Kranenburg, H. (2006). Mergers and acquisitions: their effect on the innovative performance of companies in high-tech industries. Research Policy, 17(3): 642-654.

Cohen, W., \& Levinthal, D. (1990). Absorptive capacity: a new perspective on learning and innovation. Administrative Science Quarterly, 35(1): 128-152.

Cohen, W., Goto, A., NAgata, A., Nelson, R., \& Walsh, J. (2002). R\&D spillovers, patents and the incentives to innovate in Japan and the United States. Research Policy, 31: 1349-1367.

Conn, R., Cosh, A., Guest, P., \& Hughes, A. (2005). The impact on UK acquirers of domestic, cross-border, public and private acquisitions. Journal of Business Finance \& Accounting, 32: 815-870. 
Corder, G., \& Foreman, D. (2009). Nonparametric statistics for non-statisticians. New Jersey: WILEY.

Danguy, J., De Rassenfosse, G., \& Van Pottelsberghe De La Potterie, B. (2013). On the origins of the worldwide surge in patenting: an industry perspective on the R\&Dpatent relationship. Industrial and Corporate Change, 23: 535-572.

Danzon, P., Epstein, A., \& Nicholson, S. (2007). Mergers and acquisitions in the pharmaceutical and biotech industries. Managerial and Decision Economics, 28: 307328.

de Man, A., \& Duysters, G. (2005). Collaboration and innovation: a review of the effects of mergers, acquisitions and alliances on innovation. Technovation, 25: 1377-1387.

Desyllas, P., \& Hughes, A. (2008). Sourcing technological knowledge through corporate acquisition: evidence from an international sample of high technology firms. Journal of High Technology Management Research, 18(2): 157-172.

Desyllas, P., \& Hughes, A. (2009). The revealed preferences of high technology acquirers: An analysis of the innovation characteristics of their targets. Cambridge Journal of Economics, 33: 1089-1111.

Fleming, L. (2001). Recombinant uncertainty in technological search. Management Science, 47: 117-132.

Gantumur, T., \& Stephan, A. (2011). Mergers \& acquisitions and innovation performance in the telecommunications equipment industry. Industrial and Corporate Change, 21(2): 277-314.

Gompers, P., Ishii, J., \& Metrick, A. (2003). Corporate governance and equity prices. Quarterly Journal of Economics, 118: 107-155.

Grandstrand, O., Bohlin, E., Oscarsson, C., \& Sjoberg, N. (1992). External technology acquisition in large multi-technology corporations. R\&D Management, 22: 111-133.

Griliches, Z. (1990). Patent statistics as economic indicators: A survey. Journal of Economic Literature, 4: 1661-1707. 
Hagedoorn, J., \& Duysters, G. (2002). The effect of mergers and acquisitions on the technological performance of companies in a high-tech environment. Technology Analysis \& Strategic Management, 14: 65-85.

Hall, B. (1990). The impact of corporate restructuring on industrial research and development. Brookings Papers on Economic Activity, 1: 85-136.

Hall, B., \& Ziedonis, R. (2001). The patent paradox revisited: An empirical study of patenting in the US semiconductor industry. The RAND Journal of Economics, 32(1): 101-128.

Hall, B., Jaffe, A., \& Trajtenberg, M. (2001). The NBER patent citations data file: Lessons, insights and methodological tools. NBER working paper no. 8498.

Hall, B., Jaffe, A., \& Trajtenberg, M. (2005). Market value and patent citations. The RAND Journal of Economics, 36(1): 16-38.

Harford, J. (2005). What drives merger waves? Journal of Financial Economics, 77: 529560.

Harhoff, D., Narin, F., Scherer, F., \& Vopel, K. (1999). Citation frequency and the value of patented inventions. The Review of Economics and Statistics, 81(3): 511-515.

Harrigan, K. (2003). Declining demand, divestitures and corporate strategy. Frederick MA: Beard Group. Originally published as "Strategies for declining businesses", Lexington, MA: Lexington Books, 1980.

Harrigan, K., Di Guardo, M., \& Velez, B. (2014). Dispersion measures and out-of-the-box innovation. SSRN- Social Science Research Network, SSRN:2509301.

Healy, P., Palepu, K., \& Ruback, R. (1992). Does corporate performance improve after merger? Journal of Financial Economics, 31:135-175.

Heckman, J., \& Navarro-Lozano, S. (2004). Using matching, instrumental variables, and control functions to estimate economic choice models. Review of Economics and Statistics, 86: 30-57.

Heckman, J., Ichimura, H., \& Todd, P. (1998). Characterizing selection bias using experimental data. Econometrica, 66:1017-1098. 
Henderson, R., \& Cockburn, I. (1996). Scale, scope and spillovers: the determinants of research productivity in drug discovery. The RAND Journal of Economics, 27: 32-59.

Higgins, M., \& Rodriguez, D. (2006). The outsourcing of R\&D through acquisitions in the pharmaceutical industry. Journal of Financial Economics, 80: 351-383.

Hitt, M., Harrison, J., \& Ireland, R. (2001). Mergers and acquisitions. A guide to creating value for stakeholders. Oxford University Press.

Hitt, M., Harrison, J., Ireland, R., \& Best, A. (1998). Attributes of successful and unsuccessful acquisitions of US firms. British Journal of Management, 9: 91-114.

Hitt, M., Hoskisson, R., Ireland, R., \& Harrison, J. (1991). Effects of acquisitions on R\&D inputs and outputs. Academy of Management Journal, 34: 693-706.

Hitt, M., Hoskisson, R., Johnson, R., \& Moesel, D. (1996). The market for corporate control and firm innovation. Academy of Management Journal, 39(5): 1084-1119.

Hoskisson, R., \& Hitt, M. (1990). Antecedents and performance outcomes of diversification: A review and critique of theoretical perspectives. Journal of Management, 16: 461509.

Hung, S., \& Tang, R. (2008). Factors affecting the choice of technology acquisition mode: An empirical analysis of the electronic firms of Japan, Korea and Taiwan. Technovation, 28: 551-563.

Inkpen, A., Sundaran, A., \& Rockwood, K. (2000). Cross-border acquisitions of U.S. technology assets. California Management REview, 42(3): 50-71.

Kallunki, J., Pyykkö, E., \& Laamanen, T. (2009). R\&D spending of the firm: The effect of technology mergers and acquisitions. Journal of Business Finance \& Accounting, 36(7)\&(8): 838-862.

King, D., Covin, J., \& Hegarty, W. (2003). Complementary resources and the exploitation of technological innovation. Journal of Management, 29(4): 589-606.

Kingston, W. (2001). Innovation needs patents reform. Research Policy, 30: 403-23.

Kohers, N., \& Kohers, T. (2000). The value creation petential of high-tech mergers. Financial Analysts Journal, 56(3): 40-50. 
Kozin, M., \& Young, K. (1994). Using acquisitions to buy and hone core competencies. Mergers and Acquisitions: The Dealmaker's Journal, 29(2): 21-26.

Lanjouw, J., \& Schankerman, M. (2004). Patent quality and research productivity: measuring innovation with multiple indicators. The Economic Journal, 114(495): 441-465.

Le, S., Park, J., \& Kroll, M. (2014). Differential effects of pre- and post-acquisition R\&D expenditures on post-acquisition performance. Journal of Business Research, 67: 9299.

Link, A. (1988). Acquisitions as source of technological innovation. Mergers and Acquisitions, 23(3): 36-39.

Maddala, G. (1983). Limited-deppendent and qualitative variables in econometrics. Cambridge: Cambridge University Press.

March, J. (1991). Exploration and exploitation in organizational learning. Organization Science, 2: 71-87.

Meeks, G., \& Meeks, J. (1981). Profitability measures as indicators of post-merger efficiency. The Journal of Industrial Economics, 4: 335-344.

Mehta, A., Rysman, M., \& Simcoe, T. (2010). Identifying the age profile of patent citations: new estimates of knowledge diffusion. Journal of Applied Econometrics, 25: 11791204.

Narin, F., Nome, E., \& Perry, R. (1987). Patents as indicators of corporate technological strength. Research Policy, 16: 143-155.

Ornaghi, C. (2009). Mergers and innovation in big pharma. International Journal of Industrial Organization, 27: 70-79.

Patel, D., \& Ward, M. (2011). Using patent citation patterns to infer innovation market competition. Research Policy, 40: 886-894.

Phene, A., \& Almeida, P. (2008). Innovation in multinational subsidiaries: the role of knowledge assimilation and subsidiary capabilities. Journal of International Business Studies, 39: 901-919. 
Phene, A., Fladmoe-Lindquist, K., \& Marsh, L. (2006). Breakthrough innovations in the US bio-technology industry: the effects of technological space and geographical origin. Strategic Management Journal, 27: 369-388.

Prabhu, J., Chandy, R., \& Ellis, M. (2005). The impact of acquisitions on innovation: Poison pill, placebo, or tonic? Journal of Marketing, 69(1): 114-130.

Ranft, A., \& Lord, M. (2002). Acquiring new technologies and capabilities: A grounded model of acquisition implementation. Organization Science, 13(4): 420-441.

Rau, P., \& Vermaelen, T. (1998). Glamour, value and the post-acquisition performance of acquiring firms. Journal of Financila Economics, 49(2): 223-253.

Rosenbaum, P., \& Rubin, D. (1983). The central role of the propensity score in observational studies for causal effects. Biometrika, 70: 41-55.

Rosenbaum, P., \& Rubin, D. (1984). Reducing Bias in Observational Studies Using Subclassification on the Propensity Score. Journal of the American Statistical Association, 79(387): 516-524.

Rosenkopf, L., \& Nerkar, A. (2001). Beyond local search: boundary-spanning, exploration, and impact in the optical disc industry. Strategic Management Journal, 22(4): 287306.

Sampson, R. (2007). R\&D Alliances and Firm Performance: The Impact of Technological Diversity and Alliance Organization on Innovation. Academy of Management Journal, 50(2): 364-386.

Sandner, P., \& Block, J. (2011). The market value of R\&D, patents, and trademarks. Research Policy, 40(7): 969-985.

Shaver, J. (1998). Accounting for endogeneity when assessing strategy performance: Does entry mode choice affect FDI survival? Management Science, 44(4): 571-585.

Stock, M., \& Stock, W. (2006). Intellectual property information: a comparative analysis of main information providers. Journal of the American Society for Information Science and Technology, 57(13): 1794-1803. 
Sudarsanam, S., \& Mahate, A. (2003). Glamour acquirers, method of payment and postacquisition performance: The UK evidence. Journal of Business Finance \& Accounting, 30: 299-341.

Szucs, F. (2014). M\&A and R\&D: Asymmetric effects on acquirers and targets? Research Policy, 43: 1264-1273.

Toivonen, O., Stoneman, P., \& Bosworth, D. (2002). Innovation and the market value of UK firms, 1989-1995. Oxford Bulletin of Economics and Statistics, 64 (1): 39-61.

Trajtenberg, M. (1990). A penny for your quotes: Patent citations and the value of innovation. RAND Journal of Economics, 21: 172-187.

Trajtenberg, M., Henderson, R., \& Jaffe, A. (1997). University versus corporate patents: a window on the basicness of invention. Economics of Innovation and New Technology, 5:19-50.

Tseng, F., Hsieh, C., Peng, Y., \& Chu, Y. (2011). Using patent data to analyze trends and the technological strategies of the amorphous silicon thin-film solar cell industry. Technological Forecasting \& Social Change, 78: 332-345.

Valentini, G. (2012). Measuring the effect of M\&A on patenting quantity and quality. Strategic Management Journal, 33: 336-346.

Valentini, G., \& Di Guardo, M. (2004). Design combination potential and get it done. Management Research, 2(3): 271-281.

Valentini, G., \& Di Guardo, M. (2012). M\&A and the profile of inventive activity. Strategic Organization, 10(4): 384-405.

Villalonga, B. (2004). Does diversification cause the 'diversification discount'? Financial Management, 33(2): 5-28.

Villalonga, B., \& McGahan, A. (2005). The choice among acquisitions, alliances, and divestitures. Strategic Management Journal, 26(13): 1183-1208.

Wagner, M. (2011). To explore or to exploit? An empirical investigation of acquisitions by large incumbents. Research Policy, 40: 1217-1225. 
Wilcoxon, F. (1945). Individual comparisons by ranking methods. Biometrics Bulletin, 1(6): 80-83.

Yayavarajam, S., \& Ahuja, G. (2008). Decomposability in knowledge structures and its impact on the usefulness od inventions and knowledge-base malleability. Administrative Science Quarterly, 425-455.

Zhao, X. (2009). Technological innovation and acquisitions. Management Science, 55(7): 1170-1183.

Ziedonis, R. (2004). Don't fence me in: Fragmented markets for technology and the patent acquisition strategies of firms. Management Science, 50(6): 804-820.

Zollo, M., \& Singh, H. (2004). Deliberate learning in corporate acquisitions: Post-acquisition strategies and integration capability in U.S. bank mergers. Strategic Management Journal, 25: 1233-1256. 